\title{
Metazooplankton community structure, feeding rate estimates, and hydrography in a meltwater-influenced Greenlandic fjord
}

\author{
Kam W. Tang ${ }^{1, *}$, Torkel Gissel Nielsen ${ }^{2}$, Peter Munk ${ }^{2}$, John Mortensen ${ }^{3}$, \\ Eva Friis Møller ${ }^{4}$, Kristine Engel Arendt ${ }^{3}$, Kajsa Tönnesson ${ }^{5}$, Thomas Juul-Pedersen ${ }^{3}$ \\ ${ }^{1}$ Virginia Institute of Marine Science, College of William \& Mary, Gloucester Point, Virginia 23062, USA \\ ${ }^{2}$ National Institute of Aquatic Resources, DTU Aqua, Section for Ocean Ecology and Climate, \\ Technical University of Denmark, Kavalergården 6, 2920 Charlottenlund, Denmark \\ ${ }^{3}$ Greenland Climate Research Centre, c/o Greenland Institute of Natural Resources, PO Box 570, Kivioq 2, 3900 Nuuk, Greenland \\ ${ }^{4}$ Department of Marine Ecology, National Environmental Research Institute, Aarhus University, 4000 Roskilde, Denmark \\ ${ }^{5}$ Department of Marine Ecology, University of Gothenburg, Box 461, 40530 Göteborg, Sweden
}

\begin{abstract}
In order to assess the potential responses of Greenland's coastal ecosystems to future climate change, we studied the hydrography and distribution of metazooplankton, along a transect from the slope waters beyond Fyllas Banke to the inner part of Godthåbsfjord, West Greenland, in July and August 2008, and estimated feeding rates for some of the larger species groups. Within the 4 regional domains that were covered in the study (continental slope, continental shelf, outer sill region, and main fjord basin), salty coastal water and glacial runoff mixed to various extents, and 7 water masses with specific characteristics were identified. The common large copepod species were Calanus finmarchicus, C. glacialis, C. hyperboreus, and Metridia longa. Small copepod genera included Microsetella, Pseudocalanus, and Oithona, while rotifers and gastropods (primarily pteropods) were also found in high abundance. Species could be linked to the specific water masses, e.g. Calanus spp. were primarily associated with oceanic or coastal waters, whereas M. longa, Microsetella sp., Pseudocalanus sp., and rotifers were mostly found inside the fjord. The combined biomass of the large zooplankton species $\left(5.5 \times 10^{3} \mathrm{mg} \mathrm{C} \mathrm{m}^{-2}\right)$ was less than that of the small species $(6.8 \times$ $10^{3} \mathrm{mg} \mathrm{C} \mathrm{m}^{-2}$ ) averaged across all sampled stations along the transect. Estimated in situ grazing rates for the large copepod species were $<10 \%$ of their maximum rates, indicating food limitation. The major predatory zooplankton groups, Pareuchaeta norvegica and chaetognaths, had estimated predation effects of $<1 \% \mathrm{~d}^{-1}$ on the prey community. The dominance of small zooplankton species within the fjord contradicts the traditional emphasis on large, lipid-rich zooplankton species in the arctic seas, and suggests that the planktonic food web structure inside the glacial fjord was different from that of the system outside.
\end{abstract}

KEY WORDS: Glacial fjord $\cdot$ Greenland $\cdot$ Climate change $\cdot$ Copepod $\cdot$ Grazing $\cdot$ Predation $\cdot$ Food web

\section{INTRODUCTION}

Glacial fjords and coastal waters off western Greenland are very productive, contributing $95 \%$ of Greenland's fisheries exports. They are also important feeding grounds for marine mammals (Born et al. 2003, Aquarone 2004) and wintering habitats for seabirds
(Merkel et al. 2002, Boertmann et al. 2004). Commercial and recreational fishing, hunting, and related industries are essential to the economy of the local communities. Located at the junction between land ice and sea, glacial fjords are dynamic systems that are under the influences of both terrestrial and marine processes. The functioning of the food web within the 
fjords is ultimately tied to the abundance, composition, and feeding activities of the plankton community. Climate models predict that, while the warming of surface waters will be gradual, even mild warming in glacial fjords may tip the delicate ice/water balance and lead to drastic increases in freshwater discharge into the fjords over a short period of time (Rysgaard et al. 2003, Willis et al. 2006). For example, between 1995 and 2003, an increase of $0.4^{\circ} \mathrm{C}$ in the autumn air temperature in Young Sound (northeastern Greenland) led to a $46 \%$ increase in thawing degree days and a $12 \%$ increase in thawing days (Mernild et al. 2007). More frequent breaching of ice-dammed lakes would also discharge an increasing amount of freshwater along the western Greenland coast (Krawczynski et al. 2009). It is this delicate balance that makes the plankton communities within glacial fjords particularly vulnerable to global warming.

Godthåbsfjord is located in the vicinity of Nuuk, the capital city of Greenland, just below the Arctic Circle. The fjord extends inward to the edge of the Greenland Ice Sheet, covering $2013 \mathrm{~km}^{2}$ with a mean depth of $260 \mathrm{~m}$ (Mortensen et al. 2011). A systematic monitoring program was initiated here in August 2005 by the Greenland Institute of Natural Resources. Sampling at a single station at the mouth of the fjord from 2005 to the present indicated that the metazooplankton community is dominated by small genera such as Microsetella, Oithona, and Oncaea (Rysgaard et al. 2008, Juul-Pedersen et al. 2010). A section along the fjord sampled in late spring (May 2006) showed that the biomass of small copepods was important in the middle to inner parts of the fjord, contributing $\geq 50 \%$ of the total copepod biomass (Arendt et al. 2010). High abundances of small copepods were also found in Disko Bay (Madsen et al. 2008), Young Sound (Nielsen et al. 2007), as well as in some other arctic fjords (e.g. Walkusz et al. 2003). Collectively, these studies contradict the traditional emphasis on large Calanus and Metridia species in arctic seas (e.g. Hopkins 1969, Hirche 1991, Thibault et al. 1999, Ashjian et al. 2003) and suggest very different planktonic food web structures inside the fjords relative to shelf-sea areas. A study of the hydrography within Godthåbsfjord has recently been published (Mortensen et al. 2011), providing important information for properly understanding the distribution, production, and community structure of metazooplankton, as well as their potential response to future climate change.

The present paper is a part of a multidisciplinary intensive field study in Godthåbsfjord in the summer of 2008 aimed at understanding the food web and biogeochemistry of the fjord. Here we report the hydrography, and the community structure and feeding rate estimates of the large metazooplankton, at stations along a transect from the coastal waters to the inner part of the fjord.

\section{MATERIALS AND METHODS}

Hydrography and chlorophyll a. The study was conducted in July and August 2008. The vessel RV 'Dana' (National Institute of Aquatic Resources, DTU Aqua) followed a transect of 20 stations that extended from the continental slope off Fyllas Banke to the inner part of Godthåbsfjord, which is in contact with several tidal outlet glaciers (Fig. 1). Due to logistical constraints, zooplankton sampling and experiments were done at selected stations (see below). Vertical profiles of water temperature, salinity, density, and fluorescence were obtained using a CTD (SBE 911 plus CTD from SeaBird Electronics) equipped with a Seapoint chlorophyll a fluorometer and a Biospherical/Licor sensor. Profiles were recorded from the surface to approximately $5 \mathrm{~m}$ above the bottom.

Water samples were taken from 5 depths within the upper 150 to $200 \mathrm{~m}$ at each station using 51 Niskin bottles on a rosette. Aliquots were filtered onto GF/F filters (250 to $500 \mathrm{ml}$ ) for total chlorophyll ( $\mathrm{chl} \mathrm{a}$ ) and were size fractionated by Nitex screens for $<10 \mu \mathrm{m}$ and $<50 \mu \mathrm{m}$ chl a (500 to $1000 \mathrm{ml}$ ). Chl a samples were extracted in $96 \%$ ethanol for $18 \mathrm{~h}$ before fluorescence was measured on a fluorometer (TD-700, Turner Designs) calibrated against a pure chl a standard (Turner Designs). The discrete chlorophyll measurements were used to calibrate the CTD fluorometer, and chl a concentrations were then calculated for each station from CTD fluorescence profiles. Hydrographic data were used to identify the different water masses within the fjord following the analysis of Mortensen et al. (2011).

Zooplankton species composition and abundances. Zooplankton were collected from 4 to 9 strata, depending on the total depth, at 19 of the 20 stations using both a large (MIDI) and a small (MINI) Multinet (HydroBios). The large Multinet was equipped with $300 \mu \mathrm{m}$ mesh nets, with a $0.25 \mathrm{~m}^{2}$ opening area, and could reach down to $1000 \mathrm{~m}$. Volumes filtered through the large Multinet were measured by flow meters. The small Multinet was equipped with $50 \mu \mathrm{m}$ mesh nets, with a $0.125 \mathrm{~m}^{2}$ opening area, and was deployed to a maximum depth of $300 \mathrm{~m}$. Because a flow meter was not available on the $50 \mu \mathrm{m}$ nets, filtered volumes were calculated as towed depths multiplied by net opening area, and the resulting zooplankton concentrations should be considered conservative because of potential net clogging. Upon retrieval, the nets were backflushed with seawater, and the cod end contents were emptied into sample jars and preserved in $4 \%$ buffered formaldehyde. 


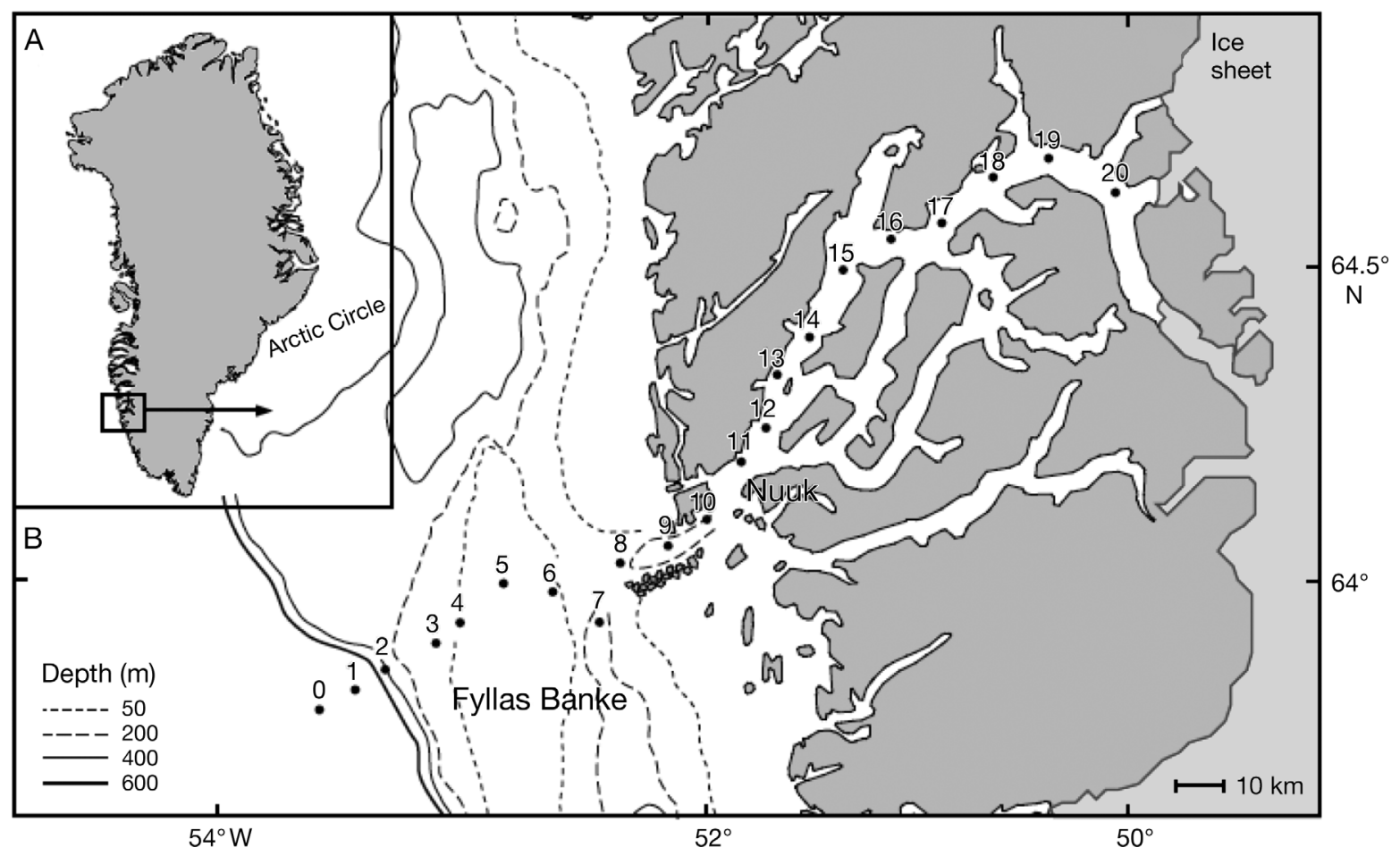

Fig. 1. Station positions along Godthåbsfjord in southwestern Greenland

Preserved zooplankton samples were processed at the Arctic Agency, Poland, for species identification and enumeration. For each sample, copepod species were identified according to developmental stages and sex, while gastropods (mainly pteropods) were grouped by size. For all identified groups, body lengths of up to 10 random individuals within each group were measured and then converted to body carbon content based on published algorithms (Table 1).

Large copepod grazing rates. Grazing by large copepods was calculated from fecal pellet production (Juul-Pedersen et al. unpubl. data) measured in shortterm incubations at noon and midnight at the 7 stations, which were sampled during the day and at night. Copepods were collected from the upper $60 \mathrm{~m}$ using a $200 \mu \mathrm{m}$ WP-2 net with a non-filtering cod end. On deck, a subsample from the cod end was immediately rinsed on a $400 \mu \mathrm{m}$ sieve submerged in running seawater. Subsamples were then distributed into 4 cylinders (40 $\mathrm{cm}$ height $\times 8 \mathrm{~cm}$ inner diameter), each equipped with a $400 \mu \mathrm{m}$ meshed bottom and filled with $1.8 \mathrm{l}$ of $10 \mu \mathrm{m}$ prescreened surface water. When surface water salinity was $<30$, water from subsurface depths was used. The procedure from the sampling of copepods to the start of the incubations took $<5 \mathrm{~min}$. The few pellets present at the beginning of the incubation were recorded. The copepods were incubated for $1 \mathrm{~h}$ in a thermo-box at surface water temperature in the dark.
At the end of the incubation, 2 samples were collected from each incubation, 1 containing the copepods on the mesh and 1 containing the fecal pellets that had fallen though the mesh. The few pellets caught on the mesh were added to the others. These samples were preserved in $2 \%$ Lugol's solution, counted, and sized. The initial pellet counts were subtracted from the final counts. Fecal pellet volume was calculated assuming a cylindrical shape and converted to carbon based on a

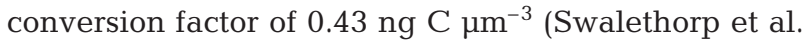
2011). Copepod biomass was calculated based on length-weight regressions for Calanus finmarchicus and C. glacialis combined (Table 1). To estimate ingestion, an assimilation efficiency of 0.68 was assumed (Conover 1966). To estimate in situ grazing rates, the rates obtained from the experiments were adjusted to temperatures at the depths where the copepods resided, using a $Q_{10}$ of 2.8 (Hansen et al. 1997). The grazing rate of the large copepods in the upper $60 \mathrm{~m}$ was calculated by multiplying the specific rates for each depth by the total biomass of the dominant copepod species $>400 \mu \mathrm{m}$ in size, i.e. Calanus finmarchicus, C. glacialis, C. hyperboreus, Metridia longa, and Pseudocalanus sp. In situ grazing rates were compared with size-specific maximum grazing rates according to Hansen et al. (1997); the differences should indicate whether the copepods were food limited. The size-specific maximum grazing rate was calculated from the 
Table 1. Algorithms used to convert body length $(L, \mu \mathrm{m})$ to body carbon content $\left(\mu \mathrm{g} \mathrm{C}\right.$ ind.$\left.^{-1}\right)$

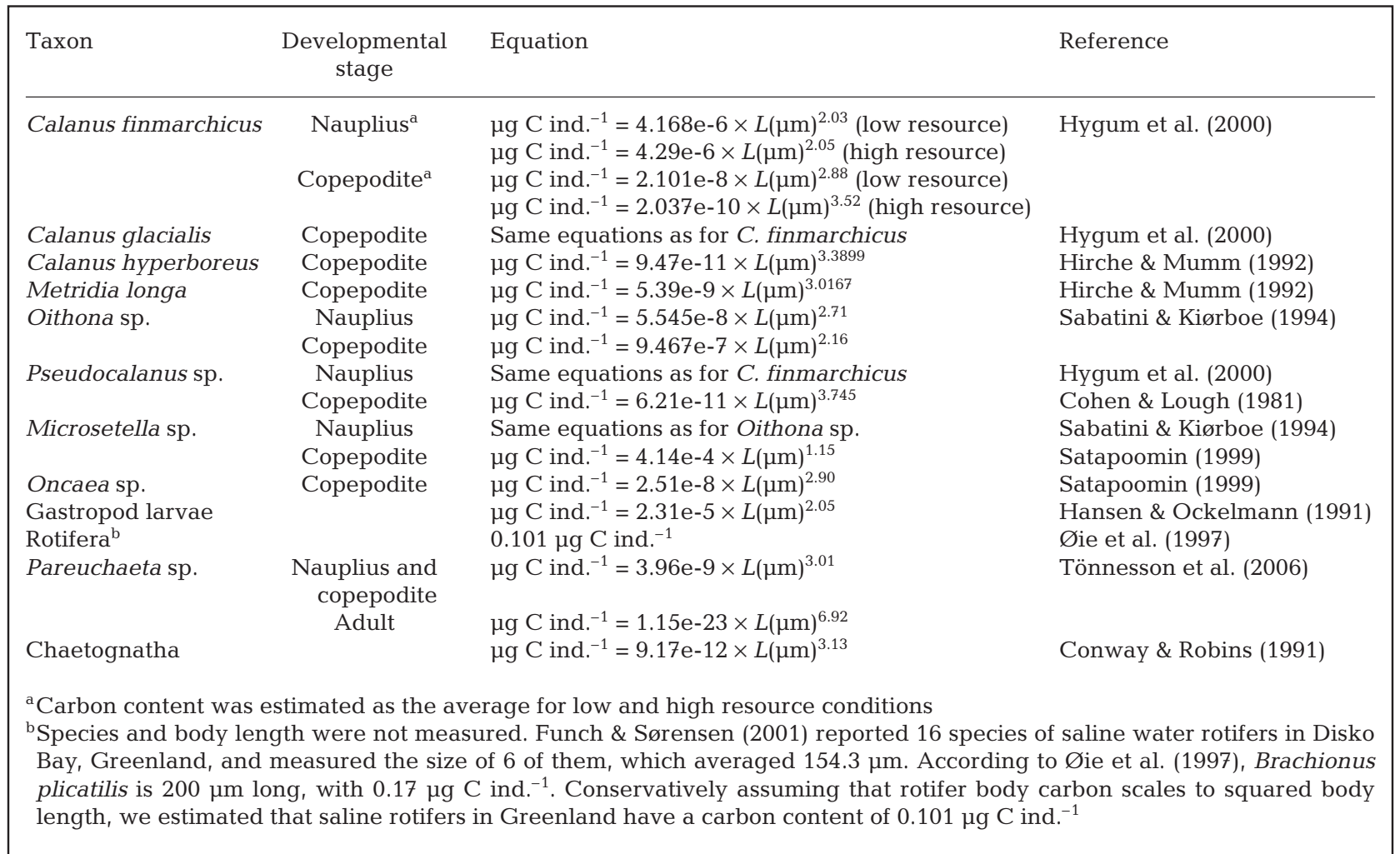

average size of the 5 dominant copepod species mentioned earlier at each station. Based on the copepod's body size, the food particle size most accessible to the copepods would be $>10 \mu \mathrm{m}$ (Berggreen et al. 1988, Hansen et al. 1997). Therefore, grazing effect on the phytoplankton was calculated based on total chl a and chl $a>10 \mu \mathrm{m}$, assuming a carbon-to-chlorophyll ratio of 47 (Møller et al. 2006).

Feeding rates of predatory zooplankton species. In situ feeding rates were estimated for 2 major predatory zooplankton groups in the fjord: Pareuchaeta norvegica and chaetognaths (Sagitta spp. and Eukrohina sp.). Animals were collected from the upper $150 \mathrm{~m}$ using WP-2 nets (mesh size: 90 and $200 \mu \mathrm{m}$ ) with nonfiltering cod ends. Water for incubation was screened through $60 \mu \mathrm{m}$ mesh to remove prey.

Gut content of Pareuchaeta norvegica was estimated from fecal pellet production based on a linear relationship between food intake and the number of pellets produced (Yen 1987, 1991, Tiselius et al. 1997, Olsen et al. 2000), assuming that each pellet represented 1 small copepod prey (Tiselius et al. 1997). Fecal pellet production experiments were done at 7 stations, 2 of which included day and night time measurements. Within $1 \mathrm{~h}$ after collection, individual $P$. norvegica females or copepodites were transferred into a $50 \mathrm{ml}$ plastic centrifuge tube filled with pre-screened water from $5 \mathrm{~m}$ and incubated in darkness at $5^{\circ} \mathrm{C}$ for ca. $60 \mathrm{~h}$ to ensure complete gut evacuation. At the end of the incubation, the content was gently poured through a $90 \mu \mathrm{m}$ sieve to collect the copepods and fecal pellets, and the number of fecal pellets was counted. To obtain feeding rate, a separate gut evacuation rate measurement was done at Stn 1 and applied to all fecal pellet production data. To measure gut evacuation rate, 15 females were gently transferred to a cylinder $(25 \mathrm{~cm}$ height $\times 10 \mathrm{~cm}$ inner diameter; $\mathrm{n}=4$ ) with a $1000 \mu \mathrm{m}$ meshed bottom. The cylinder was lowered into a 21 bucket filled with pre-screened water from the upper $50 \mathrm{~m}$ and incubated in the dark at $5^{\circ} \mathrm{C}$ for $80 \mathrm{~h}$. Every 30 to $120 \mathrm{~min}$ the cylinder was moved to a new bucket, and fecal pellets that had fallen through the meshed bottom were counted. The gut evacuation rate was determined by regression of the number of pellets produced remaining in the gut against time. The daily feeding rate (FR) of $P$. norvegica was then calculated as:

$$
\mathrm{FR}=(\mathrm{NP} \times 24) / \mathrm{DT}
$$

where NP is the number of prey per hour (assuming 1 pellet $=1$ prey) and DT is the digestion time (h) and is equal to the reciprocal of the gut evacuation rate. 
The gut contents of chaetognaths (Sagitta elegans, S. maxima, and Eukrohnia hamata) were analyzed at 12 stations, 5 of which were sampled both day and night. The number of chaetognaths used for gut content analysis ranged from 86 to 354 per staion; samples with $<20$ chaetognaths were not used. Each chaetognath was dissected and examined for remains of ingested prey. The position of prey in the gut was noted according to Øresland (1987), and the number of prey per chaetognath was determined. Individuals containing prey only in the anterior one-third of the gut might represent cod-end feeding, and were therefore not included in the analysis (Øresland 1987, Baier \& Purcell 1997). Prey were identified to species and stage, and their lengths were measured. Mandible plates of ingested copepods were converted to prey size according to Karlson \& Båmstedt (1994) and Saito \& Kiørboe (2001). If the remains did not allow for species identification, the prey copepod was recorded as unidentified. Ingested appendicularians were detected by their fecal pellets, and 3 pellets were assumed to originate from 1 individual (López-Urrutia \& Acuña 1999). Ingested chaetognaths were recognized by their grasping spines. Feeding rates were calculated in the same way as for Pareuchaeta norvegica, whereby the digestion time was estimated from in situ temperature according to Ohman (1986). Digestion time was not adjusted by a factor of 2 (Feigenbaum 1991), since prey in the anterior gut were not included in our analysis.

\section{RESULTS}

\section{Hydrographic conditions and water masses}

A distinct warm surface water mass was observed on the west side of Fyllas Banke, which coincided with a dense patch of chl a (Fig. 2). Over Fyllas Banke, salinity and density profiles were similar and showed little vertical structure, and the chl a concentration was lower (Fig. 2). There was distinct thermal stratification over the bank, but strong mixing was observed near the mid-point of the transect $(\sim 100$ $\mathrm{km})$, as indicated by the depression of the isopleths for salinity, density, and chl a (Fig. 2). A very sharp but shallow density gradient driven by differences in temperature and salinity was present in the inner part of the fjord (Fig. 2). A distinctly warm and saline water mass was present at depth in the inner fjord, and elevated chl a concentrations also extended to the deeper part of the water column (Fig. 2).

In a recent detailed hydrographic study, Mortensen et al. (2011) identified 4 regional domains in the study area: continental slope, continental shelf, outer sill region, and main fjord basin. Following the analysis by Mortensen et al. (2011), we identified the different water masses from our hydrographic data (Fig.

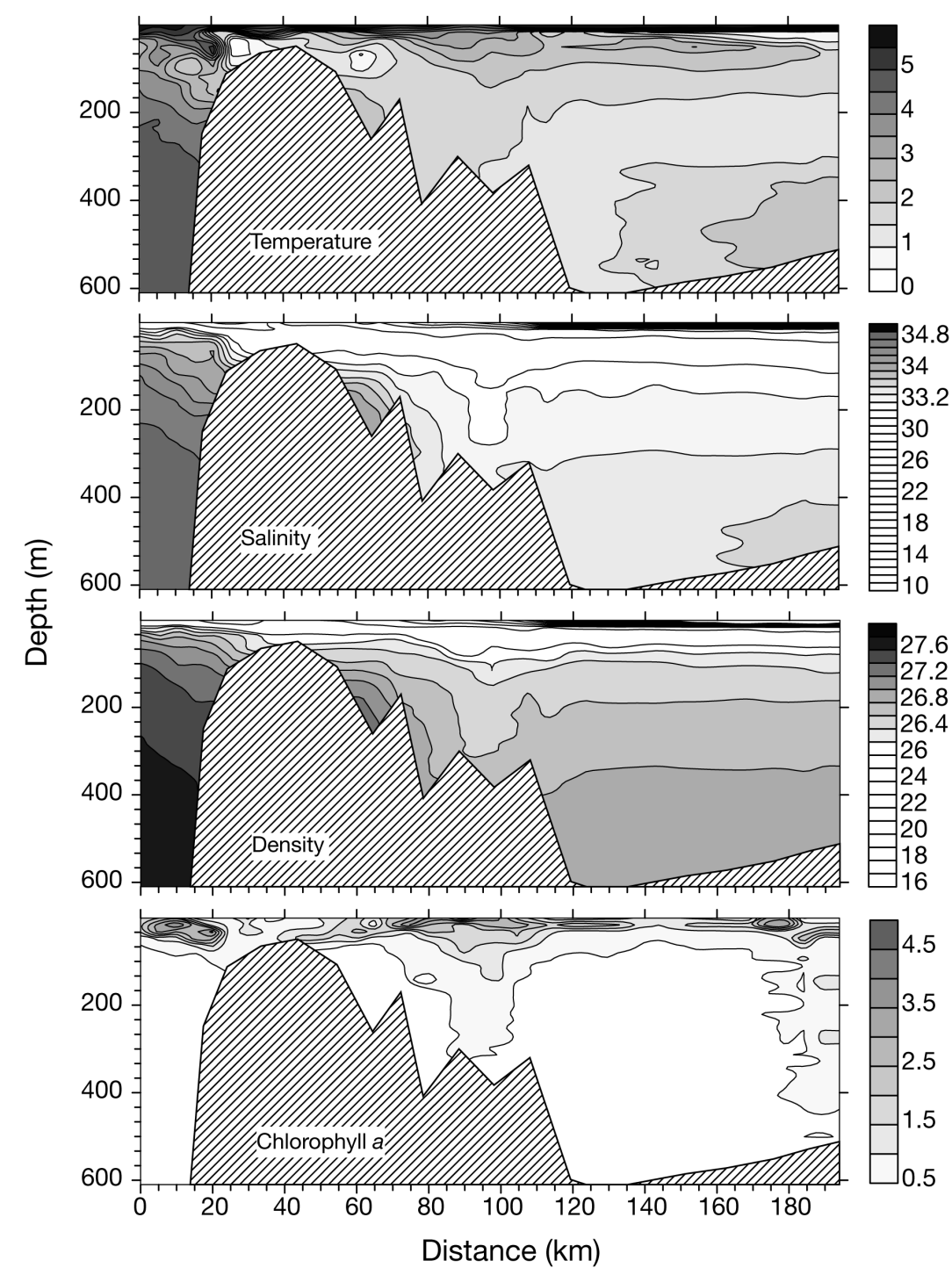

Fig. 2. Contour plots of water temperature $\left({ }^{\circ} \mathrm{C}\right)$, salinity, density $\left(\sigma_{\mathrm{T}} ; \mathrm{kg} \mathrm{m}^{-3}\right)$ and chlorophyll a $\left(\mathrm{mg} \mathrm{m}^{-3}\right)$ along the transect. Distances were measured from Station 0. Note the different contour line scales for different panels. Hatched area in each panel represents bottom topography 


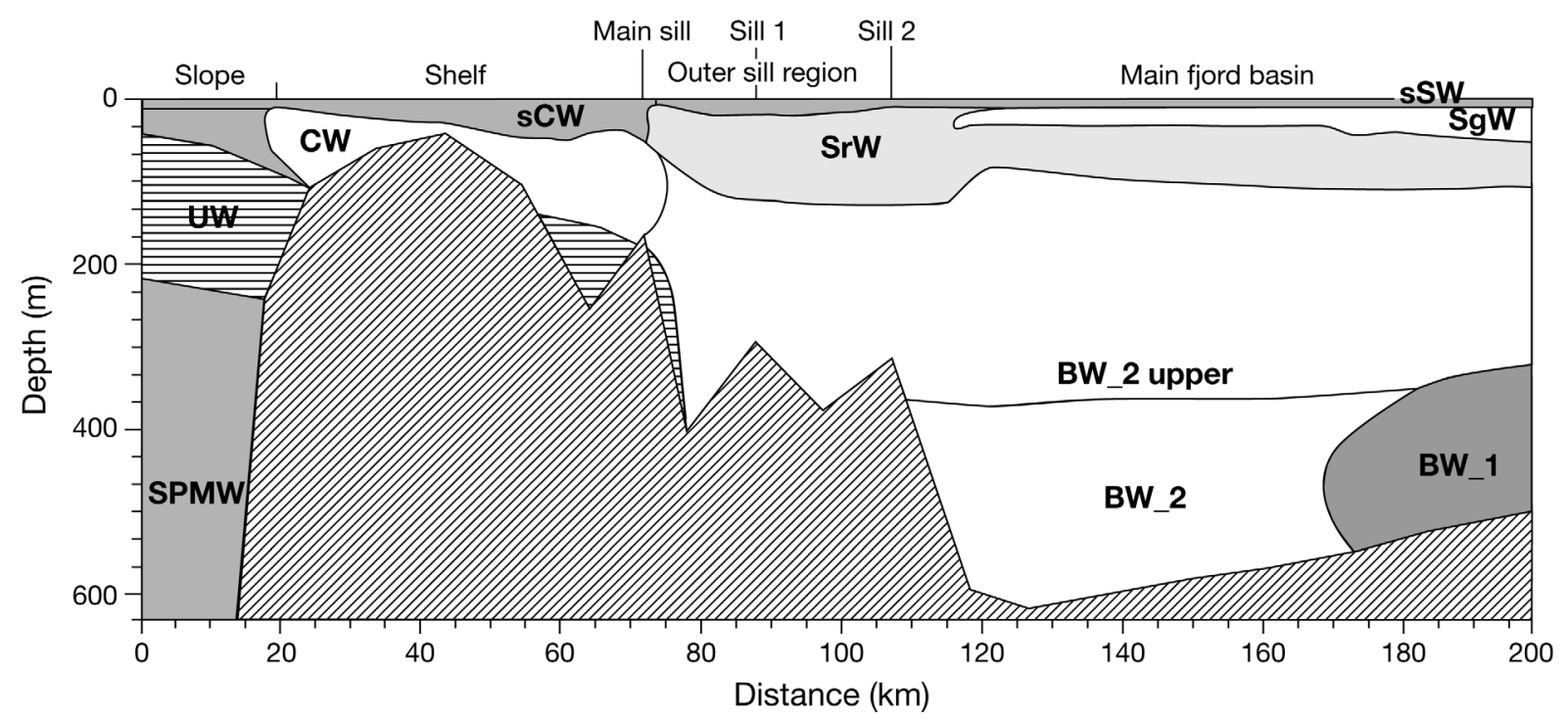

Fig. 3. Schematic drawing of water mass distribution in Godthåbsfjord in July and August 2008. Four domains were identified: slope, shelf, outer sill region, and main fjord basin. SPMW: subpolar mode water; CW: coastal water; UW: mixture of SPMW and CW; sCW: summer coastal water; SrW: sill region water; sSW: summer surface water; SgW: subglacial water; BW: basin water (further divided into inflow events 1 and 2, and upper layer). Hatched area = bottom topography

3). Subpolar mode water (SPMW) was formed by winter convection in the subpolar North Atlantic. Its temperature and salinity signatures near Nuuk were ca. $5^{\circ} \mathrm{C}$ and 35 , respectively, but they were variable, and its core (defined by its potential temperature maximum) was at $500 \mathrm{~m}$. Coastal water (CW) was observed in a wedge above the SPMW in areas close to the coast of Greenland. It had its origin in the Arctic Ocean and was modified locally as it traveled along the eastern and western coasts of Greenland. We observed a frontal zone at the shelf/slope, where CW met Labrador Sea surface water. A distinctive thin surface water layer referred to as summer coastal water (sCW) had developed over the summer, characterized by relatively high temperatures and slightly lower salinities. The water mass found in a depth range of from 100 to $200 \mathrm{~m}$ over the slope was made up of a mixture of SPMW and CW near the main sill of the fjord. In the outer sill region, the coastal water masses met the water masses from the fjord. This is an area influenced by strong tidal mixing, as evident from our hydrographic measurements (Fig. 2). In the main fjord basin, 4 identified water masses were found: summer surface water (sSW), subglacial water $(\mathrm{SgW})$, sill region water $(\mathrm{SrW})$, and basin water (BW). sSW was formed from freshwater runoff to the surface layer during summer, and was subsequently heated by solar insolation and mixing with the underlying waters. SgW was formed by subglacial freshwater discharge from tidal outlet glaciers (freshwater which enters the fjord at depth) and subsequent mixing with ambient waters (SrW and BW described in this section; Mortensen et al. 2011). SgW was found in a depth range of from 6 to $45 \mathrm{~m}$ in the inner parts of the fjord, and was characterized by low temperatures of $1^{\circ} \mathrm{C}$ and salinities of from 30 to 32. SrW was formed by mixing of water masses in the outer sill region ( $\mathrm{sSW}, \mathrm{sCW}, \mathrm{SgW}, \mathrm{CW}, \mathrm{SPMW}$, and $\mathrm{BW}$ ). The vertical extent of $\mathrm{SrW}$ was ca. $100 \mathrm{~m}$ in the outer sill region domain, and decreased slightly toward the inner part of the fjord. The deepest water mass (BW) filled the main basin of the fjord, and was a mixture of inflowing CW and SPMW. The main inflow of deep water masses into the fjord takes place during the winter and spring months (Mortensen et al. 2011). In our study we distinguished 2 different types of BW, which were derived from 2 different inflow events. The water from the first event $\left(B W \_1\right)$ was warmer and more saline than that from the second (BW_2), apparently because it contained a higher fraction of SPMW.

\section{Zooplankton composition and biomass}

Diverse communities of copepods plus several other zooplankton groups were present along the transect; the overall zooplankton taxa observed at more than one station were: (1) copepods (Calanus finmarchicus, C. glacialis, C. hyperboreus, Metridia longa, Microsetella sp., Pseudocalanus sp., Oithona sp., Oncaea sp., Microcalanus sp., Acartia sp., Paracalanus sp., Temora sp., Centropages sp., Pareuchaeta sp., Rhincalanus sp., Spinocalanus sp., Pleu- 
romamma sp., Scolecithricidae [family], Heterohabdidae [family], Aetideidae [family], Harpacticoid [order]); (2) amphipods (Gammaridae [family], Hyperiidae [family]); (3) cladocerans ( $P$ odon sp., Evadne sp.); (4) chaetognaths (Sagitta elegans, S. maxima, Eukrohnia hamata); (5) Arctic krill (Thysanoessa inermis, T. rashii); (6) rotifers; (7) isopods; (8) bryozoans; (9) siphonophores; (10) Foraminifera; (11) Echinodermata; (12) tintinnid ciliates; (13) ctenophores; (14) gastropods (mainly pteropods); (15) polychaetes; (16) cirripeds; (17) bivalves; (18) appendicularians.

The $300 \mu \mathrm{m}$ mesh Multinet captured primarily large zooplankton species, among which Calanus finmarchicus, C. glacialis, C. hyperboreus, and Metridia longa comprised most of the biomass. A comparison of $C$. finmarchicus biomass, as estimated from the 50 and $300 \mu \mathrm{m}$ net samples, showed no significant difference (Pearson's correlation coefficient $=0.763 ; \mathrm{n}=153 ; \mathrm{p}<0.01$ ). High C. finmarchicus biomass was found within the upper $200 \mathrm{~m}$ in the waters on both sides of Fyllas Banke (Fig. 4). C. glacialis was concentrated within the upper $200 \mathrm{~m}$ over the sill and just inside the fjord (Fig. 4). C. hyperboreus was found mainly over the sill and in the inner fjord below $500 \mathrm{~m}$ (Fig. 4). Unlike the Calanus species, $M$. longa was concentrated in the inner part of the fjord within the upper $200 \mathrm{~m}$ (Fig. 4).

The small Multinet (50 $\mu \mathrm{m}$ mesh) captured a vast variety of small zooplankton species, mainly in the upper $100 \mathrm{~m}$ that were undersampled or missing from the large Multinet samples (300 $\mu \mathrm{m}$ mesh). Among them the numerically dominant groups were rotifers, Microsetella sp., Pseudocalanus sp., Oithona sp., and gastropods (mainly pteropods). A very high concentration of rotifer biomass was present over the sill, with a smaller patch just over Fyllas Banke (Fig. 5). Microsetella sp. was mainly concentrated in the outer sill region of the fjord, whereas Pseudocalanus sp. was found near the surface west of Fyllas Banke and within the fjord (Fig. 5). Oithona sp. did not show any distinct horizontal zonation (Fig. 5). The biomass of gastropods was high within the upper $100 \mathrm{~m}$ west of the bank, with additional smaller patches inside the fjord (Fig. 5).
To better compare the distributions of different zooplankton species along the fjord, we calculated the integrated biomass throughout the sampled water column for each group (Fig. 6). Among the 3 Calanus species, the biomass of $C$. finmarchicus $>$ C. glacialis $>$ C. hyperboreus. The Metridia longa biomass was low, comparable to that of C. hyperboreus. Among the small zooplankton species, rotifer biomass was the highest and exceeded that of the sum of all 3 Calanus species at certain stations. Microsetella sp. had the next highest biomass followed by gastropods, Pseudocalanus sp., and Oithona sp. 


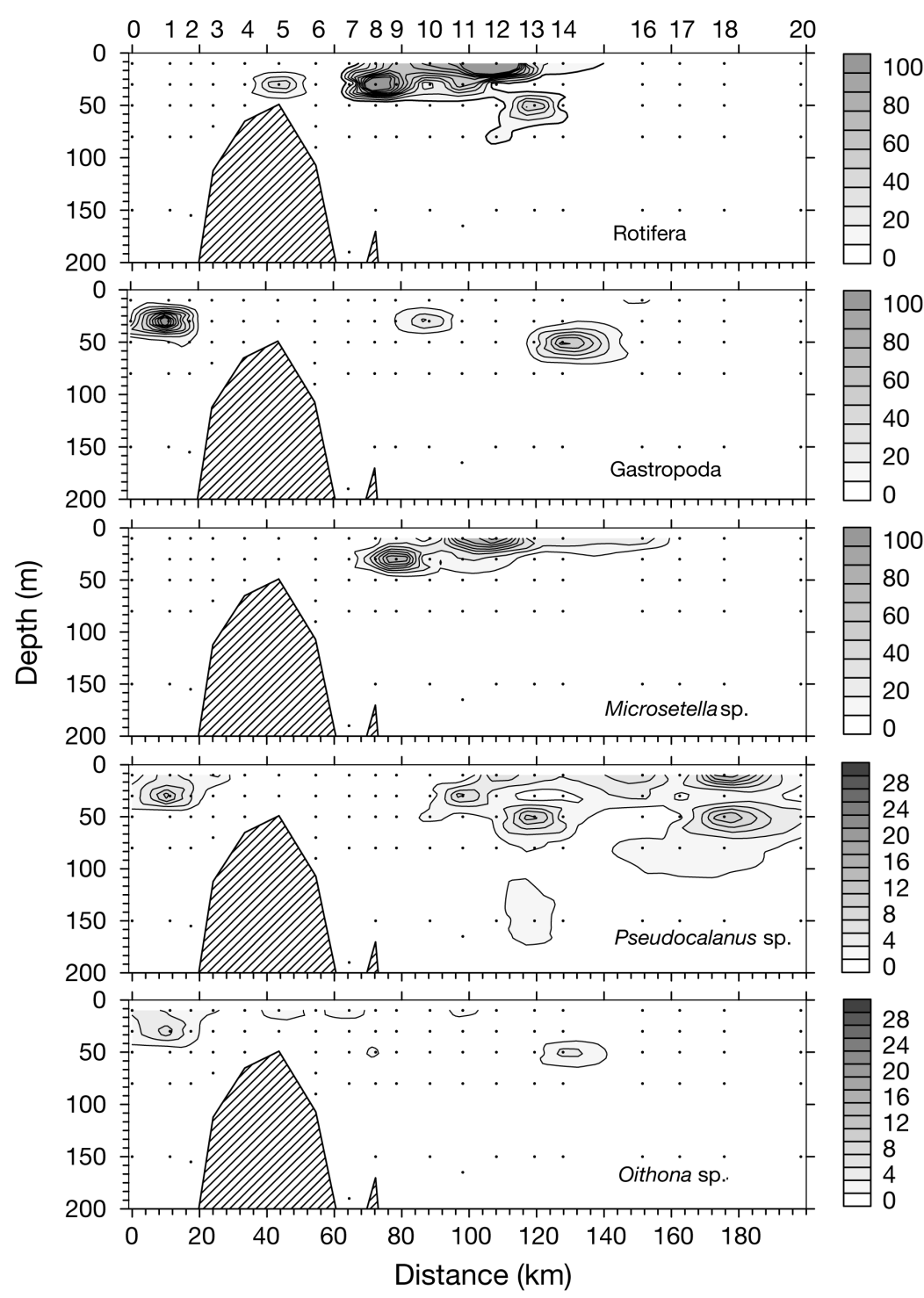

Fig. 5. Contour plots of biomass $\left(\mathrm{mg} \mathrm{C} \mathrm{m}^{-3}\right)$ of the dominant small zooplankton species from the $50 \mu \mathrm{m}$ Multinet samples along the transect. Dots are mid-points of sampling intervals. Numbers on top are stations. Tows were limited to the upper $300 \mathrm{~m}$. For stations with $>1$ sampling time, the daily averages are shown. Hatched area $=$ bottom topography

\section{Copepod grazing}

Estimated grazing by the 5 calanoid copepod species (Calanus finmarchicus, C. glacialis, C. hyperboreus, Metridia longa, and Pseudocalanus sp.) was highest

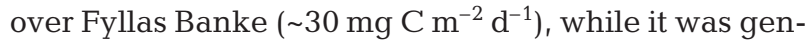
erally lower in the fjord, except at Stn 14, where there was high grazing at night (Fig. 7A). This was the result of a combination of both high grazing rates and high copepod biomass. In the fjord (Stns 10 to 20), however, the phytoplankton biomass was much higher, and the grazing effects of the large copepods on total phytoplankton (Fig. 7B) and phytoplankton $>10 \mu \mathrm{m}$ (Fig. 7C) were both very low $(<0.5 \%$ standing stock $\mathrm{d}^{-1}$ except for Stn 14).

Compared with the estimated maximum grazing potential (Hansen et al. 1997), the in situ grazing effect of the large copepods calculated from fecal pellet production was low, never exceeding $10 \%$, with most values at $\sim 5 \%$, of maximum ingestion (Fig. 7D).

\section{Predatory zooplankton species and their prey consumption}

Two major groups of predatory zooplankton were found along the transect: the carnivorous copepod (Pareuchaeta norvegica) and chaetognaths (Sagitta elegans, S. maxima, and Eukrohnia hamata) (Fig. 8). In our study region, $P$. norvegica was most abundant around Fyllas Banke and less abundant toward the inner part of the fjord. The abundance of $P$. norvegica ranged between 0 and 10.4 ind. $\mathrm{m}^{-3}$, with peak biomass recorded in the 20 to $60 \mathrm{~m}$ layer at night at Stn $9(2.05 \mathrm{mg}$ C $\mathrm{m}^{-3}$ ). P. norvegica showed strong night time upward migration at Stns 1 and 2 beyond the bank (data not shown). The proportion of females and older juveniles (Stage C5) decreased toward the inner part of the fjord. Small, dense patches of $P$. norvegica were observed in the middle section of the fjord, which appeared to overlap the distributions of Calanus spp., rotifers, and Microsetella sp.

In the fecal pellet production experiments, Pareuchaeta norvegica copepodites (Stages C4 and C5) produced 2.8 to 4.5 pellets ind. ${ }^{-1}$. Females produced fewer pellets, ranging from 1.4 to 1.6 pellets ind. ${ }^{-1}$. At stations where day-night sampling was carried out, there was no clear difference in number of pellets egested between night and day. Mortality of $P$. norvegica during the fecal pellet production experiments was low $(1 \%, \mathrm{n}=190)$. Examination of a sample of egested pellets $(n=50)$ showed remains of copepod mandibles or other parts of appendages. The measured gut evacuation rate was $-0.049 \mathrm{~h}^{-1}$, and the corresponding digestion time was $20.5 \mathrm{~h}$. Estimated feeding rates were from 1.7 to 1.9 prey $\mathrm{d}^{-1}$ for females and from 3.3 to 5.4 prey $\mathrm{d}^{-1}$ for copepodites (Fig. 9). 


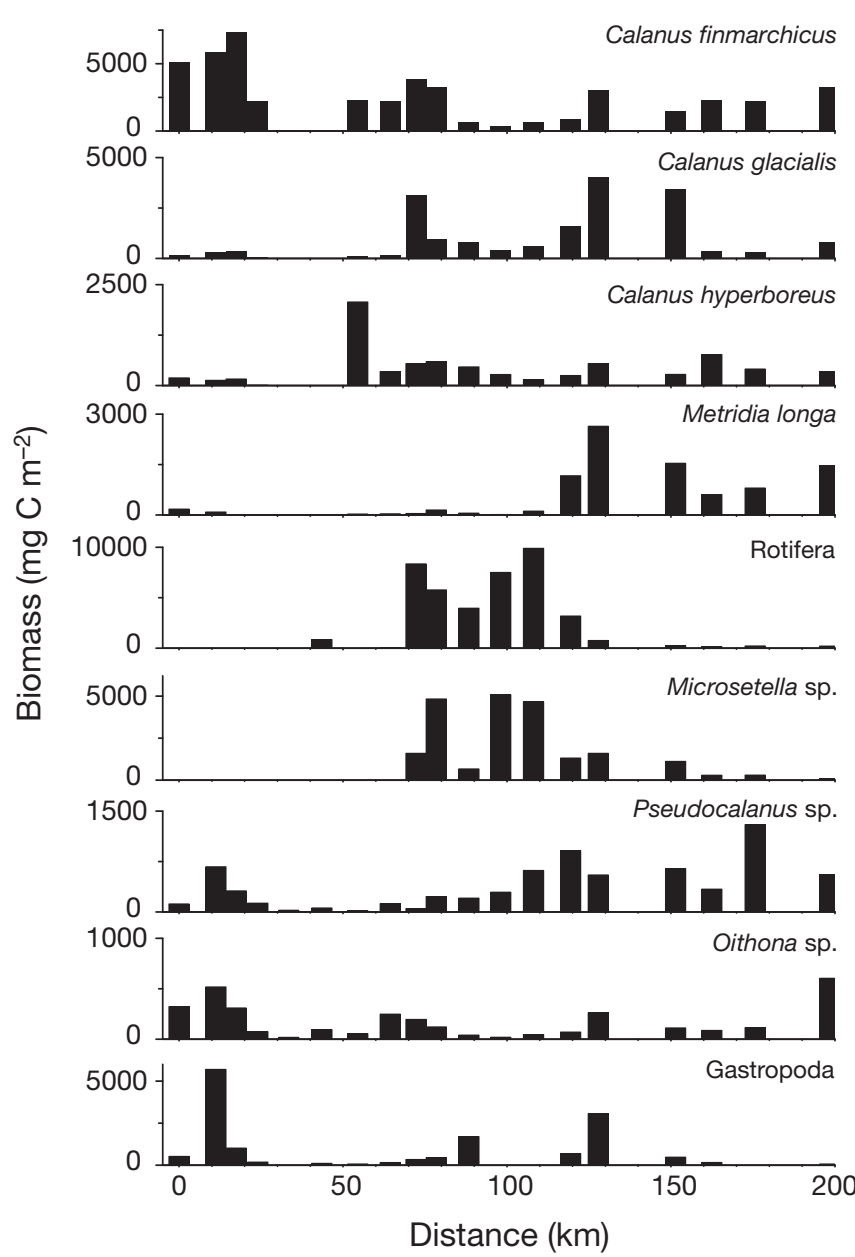

Fig. 6. Zooplankton biomass integrated throughout the sampled water column. Note the different scales on $y$-axes. For stations with $>1$ sampling time, the daily averages are shown

Chaetognaths were rare on the shelf, but Sagitta elegans was abundant within the upper $100 \mathrm{~m}$ in the middle to inner section of the fjord (Fig. 8). The peak abundance of $S$. elegans was 95 ind. $\mathrm{m}^{-3}$ in the 20 to $40 \mathrm{~m}$ layer at night at Stn 14 . The 2 other chaetognath species, S. maxima and Eukrohnia hamata, were most abundant beyond the bank (Stns 1 and 2) and in the deep outer parts of the fjord (Stns 9 and 10). The guts of 215 out of a total of 770 E. hamata examined contained prey, including copepods and appendicularians. Of the 153 S. maxima examined, 31 contained prey, which included Calanus copepodites and larger prey such as Pareuchaeta norvegica. Of the 1869 S. elegans examined, 598 contained prey. Pseudocalanus, Oithona and Metridia copepodites were the dominant prey for S. elegans. S. elegans also consumed large numbers of appendicularians. The average number of prey per chaetognath (NPC) varied between 0.15 and 0.48 among the stations (Fig. 10).
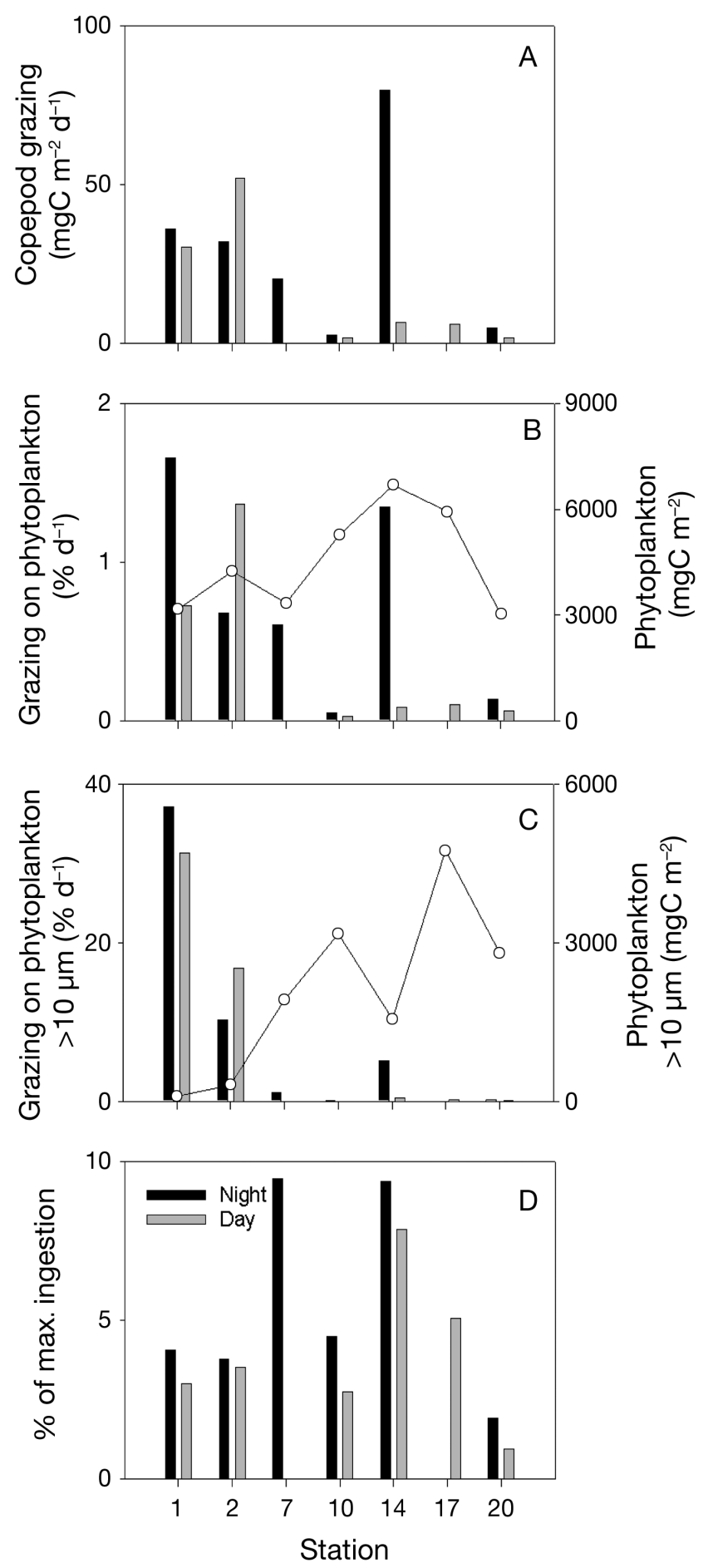

Fig. 7. Combined grazing by the 5 dominant copepod species $>400 \mu \mathrm{m}$ : Calanus finmarchicus, C. glacialis, C. hyperboreus, Metridia longa, and Pseudocalanus sp. at noon and midnight. (A) Community grazing in the upper $60 \mathrm{~m}$, (B) phytoplankton biomass (line) and grazing impact as percent standing stock per day by copepods (bars), (C) phytoplankton biomass $>10 \mu \mathrm{m}$ (line) and the grazing impact as percent standing stock per day by copepods (bars), and (D) day and night in situ grazing as percent potential maximum grazing calculated from size-specific maximum grazing rates (Hansen et al. 1997) 


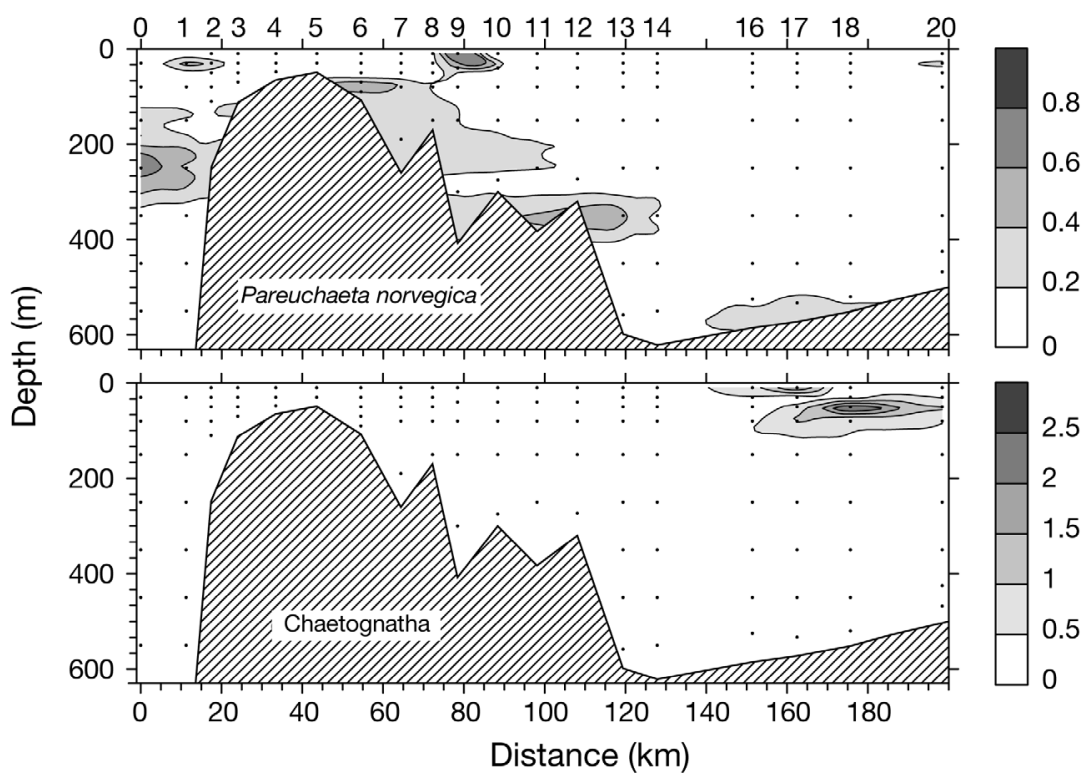

Fig. 8. Pareuchaeta norvegica, Chaetognatha. Contour plots of biomass $\left(\mathrm{mg} \mathrm{C} \mathrm{m}^{-3}\right)$ of 2 major predatory zooplankton groups in the fjord from the $300 \mu \mathrm{m}$ Multinet samples. Dots are mid-points of sampling intervals. Numbers on top are stations. For stations with $>1$ sampling time, the daily averages are shown. For $P$. norvegica, the total biomasses of all developmental stages are plotted. Hatched area $=$ bottom topography

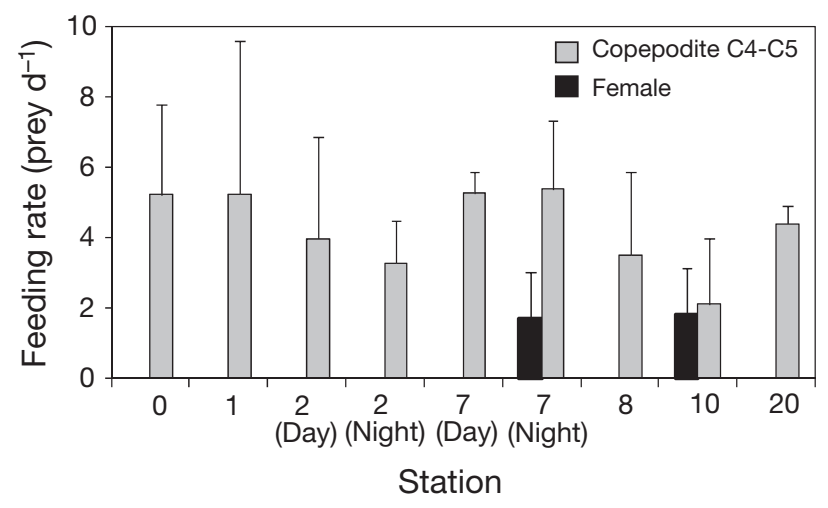

Fig. 9. Pareuchaeta norvegica. Feeding rates at different stations. Means $+\mathrm{SD}$

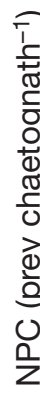

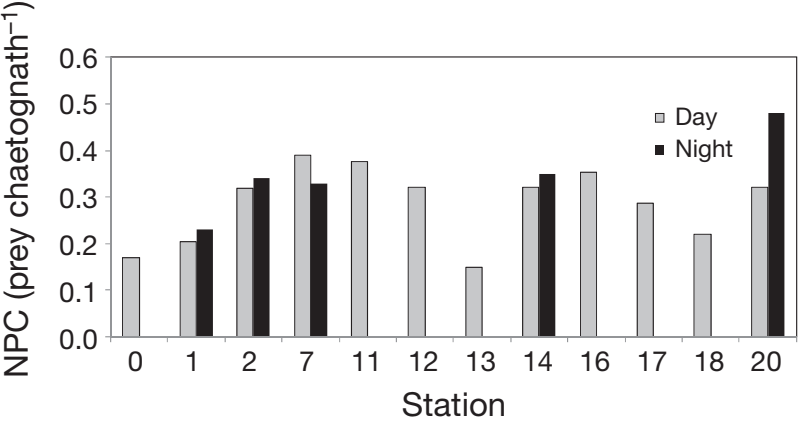

Fig. 10. Chaetognatha. Number of prey per chaetognath (NPC) at different stations. The chaetognaths included were Sagitta elegans, S. maxima, and Eukrohnia hamata

\section{Predation effect by predatory zooplankton}

The predatory effect of Pareuchaeta norvegica was calculated for Stns 1 and 2, where high abundances of this species were observed. The feeding rate by $P$. norvegica $\mathrm{C} 4$ and C5 copepodites (Fig. 9), expressed as prey per day, was taken to represent the feeding rate of all copepodites (Stages C1 to C5). Predation effect was then calculated based on feeding rates (Fig. 9), P. norvegica abundance (Fig. 8), and prey abundance (data not shown), and was expressed as the percent of copepod abundance ingested per day at each station. The predation effect of $P$. norvegica was $0.4 \%$ standing stock $\mathrm{d}^{-1}$ at Stn $1(0$ to $60 \mathrm{~m})$ and $0.2 \%$ standing stock $\mathrm{d}^{-1}$ at Stn 2 (0 to $60 \mathrm{~m})$. The highest predation effect was recorded in the 200 to $300 \mathrm{~m}$ depth range during the day at Stn 1 $\left(0.6 \%\right.$ standing stock $\left.\mathrm{d}^{-1}\right)$.

The predation effect of chaetognaths was only calculated for the dominant species, Sagitta elegans. Despite its high abundance in the middle to inner part of the fjord, its predation effect on the copepod standing stock was low $\left(0.4 \% \mathrm{~d}^{-1}\right.$ at Stn 14 and $0.2 \% \mathrm{~d}^{-1}$ at Stn 20). A comparison of prey abundance and gut content of $S$. elegans, however, showed that prey were not eaten in proportion to their abundance such that the predation effect was stronger on Pseudocalanus sp., with $S$. elegans consuming $2.4 \% \mathrm{~d}^{-1}$ of Pseudocalanus sp. standing stock at Stn 14 (20 to $40 \mathrm{~m})$ and $1.6 \% \mathrm{~d}^{-1}$ at $\operatorname{Stn} 20$ (0 to $20 \mathrm{~m})$.

\section{DISCUSSION}

\section{Hydrography and zooplankton community structure}

The water column structure appeared to influence the distribution of the zooplankton species along the fjord. Calanus finmarchicus was associated primarily with the shallow water masses above the slope and on the shelf. Both C. glacialis and C. hyperboreus were present in the inner shelf and outer sill regions associated with surface water masses, as well as with deeper water masses. C. hyperboreus biomass was conspicuously more concentrated near the bottom of the main basin. These distribution patterns suggest that the 3 populations were more connected with populations 
outside of the fjord via SPMW, CW, or BW. Metridia longa was mainly associated with surface water and, to a lesser extent, with deep water, within the basin. This implies that the $M$. longa population is more restricted to the fjord, and its life history is probably more influenced by freshwater runoff and mixing within the fjord.

Biomass levels of the small zooplankton species in Godthåbsfjord were surprisingly high. Microsetella sp. and Oithona sp. have been observed elsewhere on the southwestern Greenland shelf, but in low abundances (Pedersen et al. 2005), although our finding of high biomass for Microsetella sp. and Pseudocalanus sp. within the fjord is consistent with the observations of Arendt et al. (2010). Microsetella sp. was concentrated in the upper water column within the outer sill region, where strong vertical mixing was also observed. Microsetella sp. is known to colonize and feed on particle surfaces (Koski et al. 2005), and the strong mixing may help maintain particles, hence particle-colonizing Microsetella sp., within the water column. The observation of very high rotifer biomass in the outer sill region and above Fyllas Banke is unprecedented. The ability of rotifers to reproduce asexually may allow them to quickly exploit spring phytoplankton production (Hernroth 1983), and their populations also tend to exhibit rapid boom-and-bust cycles (Hernroth 1983, Dolan \& Gallegos 1992), resulting in patchy distributions in time and space. The distribution patterns for rotifers, Microsetella sp., and Pseudocalanus sp. in relation to water masses suggest that these populations were endemic to the fjord. The lack of distinct zonal patterns for Oithona sp. and gastropods (mainly pteropods) may reflect the broad ranges of acceptable environmental conditions for these groups and/or the presence of multiple populations.

The average biomass over all sampled stations was $5.5 \times 10^{3} \mathrm{mg} \mathrm{C} \mathrm{m}^{-2}$ for the large zooplankton species combined (from the $300 \mu \mathrm{m}$ nets) and $6.8 \times 10^{3} \mathrm{mg} \mathrm{C}$ $\mathrm{m}^{-2}$ for the small zooplankton species combined (from the $50 \mu \mathrm{m}$ nets). Hence, sampling using only largemesh-sized nets would have greatly underestimated the total zooplankton community diversity and biomass in Godthåbsfjord. The ecological roles of many of these small zooplankton species that dominate within the fjord remain unknown. Due to their small size, they likely consume small phytoplankton and micro-zooplankton (Møller et al. 2006) or live in association with particle aggregates, and they, in turn, may become prey for larger zooplankton and larval fish (Simonsen et al. 2006). In addition, the smaller species may numerically respond faster to environmental changes than larger species, which have longer and more complex life cycles. Given the fact that the biomass of small zooplankton species was comparable with or even ex- ceeded that of the large zooplankton species at some stations, and that small species tend to have higher growth rates (Hansen et al. 1997), these small zooplankton likely contribute substantial and yet unquantified biological production to the system (Madsen et al. 2008).

\section{Zooplankton feeding}

The low estimated copepod grazing rates (Fig. 7) relative to the expected maximum grazing rates suggest that the copepods $(>400 \mu \mathrm{m})$ might have been food limited. This may be particularly true at offshore stations, where phytoplankton biomass in the size range most accessible to the copepods ( $>10 \mu \mathrm{m}_{\text {; }}$ Berggreen et al. 1988, Hansen et al. 1997) was low and grazing impact was high. Within the fjord, a significant fraction of the phytoplankton was of the genus Phaeocystis (Arendt et al. 2010), which is usually not grazed very effectively by suspension-feeding copepods (Nejstgaard et al. 2007). In addition, the low copepod biomass within the fjord also contributed to the low grazing effect. Overall, direct trophic linkage between phytoplankton and the large copepods appeared weak along the transect.

The estimated predation rates of Pareuchaeta norvegica were in agreement with other measurements in the field (Tönnesson et al. 2006) and in the laboratory (Olsen et al. 2000). The estimated predation impact of P. norvegica was low $\left(<1 \% \mathrm{~d}^{-1}\right)$, suggesting that its top-down effect on the copepod community was weak. The overall predation impact by chaetognaths also seemed low, but was consistent with previous reports (Kimmerer 1984, Drits \& Utkina 1988, Stuart \& Verheye 1991). However, chaetognaths appeared to select for Pseudocalanus sp. and might have had a greater impact on this species than on others. Because our calculations relied on gut content analysis, however, predation impact would have been underestimated if these predatory species ingested prey, such as rotifers, that do not have preservable body parts.

\section{Climate change and the planktonic food web in Godthåbsfjord}

The Greenland Ice Sheet continues to be affected by global warming (Krabill et al. 2000, Chen et al. 2006, Hanna et al. 2008), and recent data suggest that melting has intensified along the coast, especially in southwestern Greenland (Krabill et al. 2000, 2004, Johannessen et al. 2005, Rignot et al. 2010). The very different zooplankton species compositions between the fjord and the slope-shelf region suggest that the 
respective planktonic food webs will respond to climate change differently.

The East Greenland Current flows south from the high arctic along the east coast and meets with the Irminger Current derived from the North Atlantic Current. Both currents contribute to the formation of the West Greenland Current that flows north along the west coast (Buch et al. 2004). High abundances of Calanus spp. have been observed beyond the shelf off the coast of SW Greenland (Head et al. 2000, 2003). Additional Calanus populations are also present within the Irminger Current, off the southeast coast of Greenland (Astthorsson \& Gislason 2003, Heath et al. 2008). These remote populations could be connected to the Calanus populations in Godthåbsfjord and buffer them against fluctuations due to local climate change. To test this hypothesis, there is a clear need to investigate the population genetic variation of the Calanus populations to discern the extent of connection between Godthåbsfjord and the neighboring regions (Bucklin et al. 2000).

Most of the existing ocean-climate models operate down to the coastal shelf spatial scale, but do not extend into glacial fjords. Understanding the biological oceanography (i.e. the interaction between hydrography and the planktonic food web structure of glacial fjords) will be crucial for predicting climate change impacts on these delicate sea/ice junctures and on the resident populations that rely on their natural resources. Here we have described the hydrographic structure of Godthåbsfjord, along with the community structure, grazing, and predation among its metazooplankton. Increased ice melting will intensify freshwater intrusion into the fjord, which may, in turn, have a negative influence on oceanic or coastal zooplankton species, but favor resident self-sustaining species. In particular, the increasing dominance of rotifers and other small zooplankton species in the outer sill and main fjord basin regions might yield a trophic structure with an added level. Because the phytoplankton composition is expected to shift toward one with a smaller cell size (Sommer \& Lengfellner 2008), this could lead to a closer coupling between primary production and grazing by microzooplankton. However, a shift towards a community dominated by small and less lipidrich zooplankton species could also greatly impact the transfer of lipid and essential fatty acids up the food chain, affecting production at higher trophic levels (Falk-Petersen et al. 2007).

Acknowledgements. This study (ECOGREEN) was funded by a grant from the Commission for Scientific Research in Greenland (KVUG), the Danish Natural Sciences Research Council, and is a contribution of the Greenland Climate Research Centre. K.W.T. also received support from the United States National Science Foundation (NSF) Ocean Sciences 0814558.
K.T. received support from Marie Curie FP7-PEOPLE-ERG2008 No. 239420 and the YMER-80 Foundation. We thank 3 reviewers and the editors for their constructive criticism. This article is Contribution 3169 of the Virginia Institute of Marine Science, College of William \& Mary.

\section{LITERATURE CITED}

Aquarone M (2004) Body composition, field metabolic rate and feeding ecology of walrus (Odobenus rosmarus) in northeast Greenland. PhD thesis, National Environmental Research Institute, Roskilde

Arendt KE, Nielsen TG, Rysgaard S, Tönnesson K (2010) Differences in plankton community structure along the Godthåbsfjord, from the Greenland Ice Sheet to offshore waters. Mar Ecol Prog Ser 401:49-62

Ashjian CJ, Campbell RG, Welch HE, Butler M, Keuren DV (2003) Annual cycle of abundance, distribution, and size in relation to hydrography of important copepod species in the western Arctic Ocean. Deep-Sea Res I 50:1235-1261

Astthorsson OS, Gislason A (2003) Seasonal variations in abundance, development and vertical distribution of Calanus finmarchicus, C. hyperboreus and C. glacialis in the East Icelandic Current. J Plankton Res 25:843-854

Baier CT, Purcell JE (1997) Trophic interactions of chaetognaths, larval fish, and zooplankton in the South Atlantic Bight. Mar Ecol Prog Ser 146:43-53

Berggreen U, Hansen B, Kiørboe T (1988) Food size spectra, ingestion and growth of the copepod Acartia tonsa during development: implications for determination of copepod production. Mar Biol 99:341-352

Boertmann D, Lyngs P, Merkel FR, Mosbech A (2004) The significance of Southwest Greenland as winter quarters for seabirds. Bird Conserv Int 14:87-112

Born EW, Rysgaard S, Ehlmé G, Sejr M, Acquarone M, Levermann N (2003) Underwater observations of foraging freeliving Atlantic walruses (Odobenus rosmarus rosmarus) and estimates of their food consumption. Polar Biol 26: 348-357

> Buch E, Pedersen SA, Ribergaard MH (2004) Ecosystem variability in West Greenland waters. J Northwest Atl Fish Sci $34: 13-28$

Bucklin A, Astthorsson OS, Gislason A, Allen LD, Smolenack SB, Wiebe PH (2000) Population genetic variation of Calanus finmarchicus in Icelandic waters: preliminary evidence of genetic differences between Atlantic and Arctic populations. ICES J Mar Sci 57:1592-1604

Chen JL, Wilson CR, Tapley BD (2006) Satellite gravity measurements confirm accelerated melting of Greenland Ice Sheet. Science 313:1958-1960

> Cohen RE, Lough RG (1981) Length-weight relationships for several copepods dominant in the Georges Bank-Gulf of Maine area. J Northwest Atl Fish Sci 2:47-52

> Conover RJ (1966) Assimilation of organic matter by zooplankton. Limnol Oceanogr 11:338-345

Conway DVP, Robins DB (1991) Collection and chemical analysis of chaetognaths and changes due to preservation. In: Bone Q, Kapp H, Pierrot-Bults AC (eds) The biology of chaetognaths. Oxford University Press, New York, NY, p 137-146

> Dolan JR, Gallegos CC (1992) Trophic role of planktonic rotifers in the Rhode River Estuary, spring-summer 1991. Mar Ecol Prog Ser 85:187-199

Drits AV, Utkina SV (1988) Feeding of Sagitta setosa in layer of daytime plankton accumulation in the Black Sea. Oceanology (Mosc) 28:781-785 
Falk-Petersen S, Pavlov V, Timofeev S, Sargent JR (2007) Climate variability and possible effects on arctic food chains: the role of Calanus. In: Ørbæk JB, Kallenborn R, Tombre I, Hegseth EN, Falk-Petersen S, Hoel AH (eds) Arctic alpine ecosystems. Springer, Berlin, p 147-165

Feigenbaum D (1991) Food and feeding behavior. In: Bone Q, Kapp H, Pierrot-Bults AC (eds) The biology of chaetognaths. Oxford University Press, New York, NY, p 45-54

Funch P, Sørensen MV (2001) Rotifers in saline waters from Disko Island, West Greenland. Hydrobiologia 446/447: 273-282

> Hanna E, Huybrechts P, Steffen K, Cappelen J and others (2008) Increased runoff from melt from the Greenland Ice Sheet: a response to global warming. J Clim 21: 331-341

> Hansen B, Ockelmann KW (1991) Feeding behaviour in larvae of the opisthobranch Philine aperta. I. Growth and functional response at different developmental stages. Mar Biol 111:255-261

> Hansen PJ, Bjørnsen PK, Hansen BW (1997) Zooplankton grazing and growth: scaling within the $2-2000 \mu \mathrm{m}$ body size range. Limnol Oceanogr 42:687-704

> Head EJH, Harris LR, Campbell RW (2000) Investigations on the ecology of Calanus spp. in the Labrador Sea. I. Relationship between the phytoplankton bloom and reproduction and development of Calanus finmarchicus in spring. Mar Ecol Prog Ser 193:53-73

> Head EJH, Harris LR, Yashayaev I (2003) Distributions of Calanus spp. and other mesozooplankton in the Labrador Sea in relation to hydrography in spring and summer (1995-2000). Prog Oceanogr 59:1-30

> Heath MR, Rasmussen J, Ahmed Y, Allen J and others (2008) Spatial demography of Calanus finmarchicus in the Irminger Sea. Prog Oceanogr 76:39-88

> Hernroth L (1983) Marine pelagic rotifers and tintinnids important trophic links in the spring plankton community of the Gullmar Fjord, Sweden. J Plankton Res 5:835-846

Hirche HJ (1991) Distribution of dominant calanoid copepod species in the Greenland Sea during late fall. Polar Biol 11:351-362

> Hirche HJ, Mumm N (1992) Distribution of dominant copepods in the Nansen Basin, Arctic Ocean, in summer. DeepSea Res Part A 39:485-505

> Hopkins TL (1969) Zooplankton standing crop in the Arctic basin. Limnol Oceanogr 14:80-95

> Hygum BH, Rey C, Hansen BW (2000) Growth and development rates of Calanus finmarchicus nauplii during a diatom spring bloom. Mar Biol 136:1075-1085

Johannessen OM, Khvorostovsky K, Miles MW, Bobylev LP (2005) Recent ice-sheet growth in the interior of Greenland. Science 310:1013-1016

Juul-Pedersen T, Rysgaard S, Batty P, Mortensen J and others (2010) Nuuk Basic - the MarineBasic Programme 2009. In: Jensen LM, Rasch M (eds) Nuuk ecological research operations, 3rd Annual Report 2009. National Environmental Research Institute, Aarhus University, Aarhus

Karlson K, Båmstedt U (1994) Planktivorous predation on copepods. Evaluation of mandible remains in predator guts as a quantitative estimate of predation. Mar Ecol Prog Ser 108:79-89

Kimmerer WJ (1984) Selective predation and its impact on prey of Sagitta enflata (Chaetognatha). Mar Ecol Prog Ser 15:55-62

> Koski M, Kiørboe T, Takahashi K (2005) Benthic life in the pelagic: aggregate encounter and degradation rates by pelagic harpacticoid copepods. Limnol Oceanogr 50: 1254-1263
Krabill W, Abdalati W, Frederick E, Manizade S and others (2000) Greenland Ice Sheet: high-elevation balance and peripheral thinning. Science 289:428-430

- Krabill W, Hanna E, Huybrechts P, Abdalati W and others (2004) Greenland ice sheet: increased coastal thinning. Geophys Res Lett 31:L24402. doi:10.1029/ 2008GL036765

$>$ Krawczynski MJ, Behn MD, Das SB, Joughin I (2009) Constraints on the lake volume required for hydro-fracture through ice sheets. Geophys Res Lett 36:L10501. doi:10. 1029/2004GL021533

> López-Urrutia A, Acuña JL (1999) Gut throughput dynamics in the appendicularian Oikopleura dioica. Mar Ecol Prog Ser 191:195-205

> Madsen SD, Nielsen TG, Hansen BW (2008) Annual population development and production by small copepods in Disko Bay, western Greenland. Mar Biol 155:63-77

Merkel FR, Mosbech A, Boertmann D, Grøndahl L (2002) Winter seabird distribution and abundance off southwestern Greenland, 1999. Polar Res 21:17-36

Mernild SH, Sigsgaard C, Rasch M, Hasholt B, Hansen BU, Stjernholm M, Petersen D (2007) Climate, river discharge and suspended sediment transport in the Zackenberg River drainage basin and Yound Sound/Tyrolerfjord, Northeast Greenland. In: Rysgaard S, Glud RN (eds) Carbon cycling in Arctic marine ecosystems: case study Young Sound. Bioscience 58:24-43

> Møller EF, Nielsen TG, Richardson K (2006) The zooplankton community in the Greenland Sea: composition and role in carbon turnover. Deep-Sea Res I 53:76-93

> Mortensen J, Lennert K, Bendtsen J, Rysgaard S (2011) Heat sources for glacial melt in a sub-Arctic fjord (Godthåbsfjord) in contact with the Greenland Ice Sheet. J Geophys Res 116:C01013. doi:10.1029/2010JC006528

> Nejstgaard JC, Tang KW, Steinke M, Dutz J, Koski M, Antajan E, Long J (2007) Zooplankton grazing on Phaeocystis: a quantitative review and future challenges. Biogeochemistry $83: 147-172$

Nielsen TG, Ottosen LD, Hansen BW (2007) Structure and function of the pelagic ecosystem in Young Sound, NE Greenland. In: Rysgaard S, Glud RN (eds) Carbon cycling in Arctic marine ecosystems: case study Young Sound. Bioscience 58:88-107

> Ohman MD (1986) Predator-limited population growth of the copepod Pseudocalanus sp. J Plankton Res 8:673-713

> Øie G, Makridis P, Reitan KI, Olsen Y (1997) Protein and carbon utilization of rotifers (Brachionus plicatilis) in first feeding of turbot larvae (Scophthalmus maximus L.) Aquaculture 153:103-122

Olsen EM, Jørstad T, Kaartvedt S (2000) The feeding strategies of two large marine copepods. J Plankton Res 22: 1513-1528

Øresland V (1987) Feeding of the chaetognaths Sagitta elegans and $S$. setosa at different seasons in Gullmarsfjorden, Sweden. Mar Ecol Prog Ser 39:69-79

> Pedersen SA, Ribergaard MH, Simonsen CS (2005) Microand mesozooplankton in Southwest Greenland waters in relation to environmental factors. J Mar Syst 56:85-112

Rignot E, Koppes M, Velicogna I (2010) Rapid submarine melting of the calving faces of West Greenland glaciers. Nat Geosci 3:473-476. doi:10.1038/ngeo765

Rysgaard S, Vang T, Stjernholm M, Rasmussen B, Windelin A, Kiilsholm S (2003) Physical conditions, carbon transport, and climate change impacts in a Northeast Greenland fjord. Arct Antarct Alp Res 35:301-312

Rysgaard S, Arendt KE, Frederiksen M, Egevang C and others (2008) Nuuk Basic-the MarineBasic Programme 2005-2006. In: Jensen LM, Rasch M (eds) Nuuk ecological 
research operations, 1st Annual Report, 2007. Danish Polar Center, Copenhagen, p 54-73

Sabatini M, Kiørboe T (1994) Egg production, growth and development of the cyclopoid copepod Oithona similis. J Plankton Res 16:1329-1351

Saito H, Kiørboe T (2001) Feeding rates in the chaetognath Sagitta elegans: effects of prey size, prey swimming behaviour and small-scale turbulence. J Plankton Res 23: 1385-1398

Satapoomin S (1999) Carbon content of some common tropical Andaman Sea copepods. J Plankton Res 21:2117-2123

Simonsen CS, Munk P, Folkvord A, Pedersen SA (2006) Feeding ecology of Greenland halibut and sandeel larvae off West Greenland. Mar Biol 149:937-952

Sommer U, Lengfellner K (2008) Climate change and the timing, magnitude, and composition of the phytoplankton spring bloom. Glob Change Biol 14:1199-1208

Stuart V, Verheye HM (1991) Diel migration and feeding patterns of the chaetognath, Sagitta friderici, off the west coast of South Africa. J Mar Res 49:493-515

Swalethorp R, Kjellerup S, Dünweber M, Nielsen TG, Møller EF, Rysgaard S, Hansen BW (2011) Grazing, egg production and biochemical evidence of differences in the life strategies of Calanus finmarchicus, C. glacialis and C. hyperboreus in Disko Bay, western Greenland. Mar Ecol
Prog Ser 429:125-144

> Thibault D, Head EJH, Wheeler PA (1999) Mesozooplankton in the Arctic Ocean in summer. Deep-Sea Res I 46:1391-1415

> Tiselius P, Jonsson PR, Kaartvedt S, Olsen EM, Jøstad T (1997) Effects of copepod foraging behavior on predation risk: an experimental study of the predatory copepod Pareuchaeta norvegica feeding on Acartia clause and A. tonsa (Copepoda). Limnol Oceanogr 42:164-170

> Tönnesson K, Nielsen TG, Tiselius P (2006) Feeding and production of the carnivorous copepod Pareuchaeta norvegica in the Skagerrak. Mar Ecol Prog Ser 314:213-225

Walkusz W, Storemark K, Skau T, Gannefors C, Lundberg M (2003) Zooplankton community structure; a comparison of fjords, open water and ice stations in the Svalbard area. Polish Polar Res. 24:149-165

Willis K, Cottier F, Kwasniewski S, Wold A, Falk-Petersen S (2006) The influence of advection on zooplankton community composition in an Arctic fjord (Kongsfjorden, Svalbard). J Mar Syst 61:39-54

- Yen J (1987) Predation by the carnivorous marine copepod, Euchaeta norvegica Boeck, on eggs and larvae of the North Atlantic cod Gadus morhua L. J Exp Mar Biol Ecol 112:283-296

Yen J (1991) Predatory feeding behavior of an Antarctic marine copepod, Euchaeta antarctica. Polar Res 10:433-442

Submitted: November 12, 2010; Accepted: April 29, 2011

Proofs received from author(s): July 12, 2011
Editorial responsibility: Matthias Seaman,

Oldendorf/Luhe, Germany 